\title{
Cloning, purification and characterisation of a recombinant purine nucleoside phosphorylase from Bacillus halodurans Alk36
}

\author{
Daniel F. Visser • Fritha Hennessy • \\ Konanani Rashamuse $\cdot$ Maureen E. Louw • \\ Dean Brady
}

Received: 22 September 2009/ Accepted: 16 December 2009/Published online: 9 January 2010

(C) The Author(s) 2010. This article is published with open access at Springerlink.com

\begin{abstract}
A purine nucleoside phosphorylase from the alkaliphile Bacillus halodurans Alk36 was cloned and overexpressed in Escherichia coli. The enzyme was purified fivefold by membrane filtration and ion exchange. The purified enzyme had a $V_{\max }$ of $2.03 \times 10^{-9} \mathrm{~s}^{-1}$ and a $K_{\mathrm{m}}$ of $206 \mu \mathrm{M}$ on guanosine. The optimal $\mathrm{pH}$ range was between 5.7 and 8.4 with a maximum at $\mathrm{pH}$ 7.0. The optimal temperature for activity was $70^{\circ} \mathrm{C}$ and the enzyme had a half life at $60^{\circ} \mathrm{C}$ of $20.8 \mathrm{~h}$.
\end{abstract}

Keywords Nucleoside phosphorylase - Biocatalysis . Guanosine $\cdot$ 5-Methyluridine $\cdot$ Bacillus halodurans

\section{Abbreviation \\ BHPNP1 Bacillus halodurans purine nucleoside phosphorylase 1}

\section{Introduction}

5-Methyluridine is a non-natural nucleoside that can be used as an intermediate in the synthesis of thymidine, and

Communicated by L. Huang.

D. F. Visser · F. Hennessy ( $₫)$ - K. Rashamuse · D. Brady

Enzyme Technologies Group, CSIR Biosciences,

Private Bag X2, Modderfontein,

Johannesburg 1645, South Africa

e-mail: fhennessy@csir.co.za

M. E. Louw

Microbial Expression Systems, CSIR Biosciences,

PO Box 395, Pretoria 0001, South Africa in the synthesis of nucleoside analogues AZT and stavudine, both of which are used in highly active antiretroviral treatment of HIV/AIDS patients. As the compound needs to be formed as a single isomer, 5-methyluridine can be synthesised through the transglycosylation of D-ribose-1phosphate, using guanosine as a donor, and thymine as receptor (Ge et al. 2009; Medici et al. 2008; Rocchietti et al. 2004). Enzymes provide regio- and stereoselectivity, and hence are an ideal option for nucleoside transglycosylation (Prasad et al. 1999; Utagawa 1999). The hydrolysis reaction for the ribose decoupling reaction can be achieved using purine nucleoside phosphorylase (PNPase; EC 2.4.2.1) (Fig. 1).

However, the reagents guanosine and thymine are relatively insoluble, and are particulate substrates with poor reaction kinetics. The most effective method of solubilising these materials is in hot aqueous solutions. Therefore, it would be preferable to utilise thermostable enzymes to catalyse these reactions. Enzymes that can be used in this transglycosylation reaction include PNPase, thymidine phosphorylase (TPase; EC 2.4.2.4) and uridine phosphorylase (UPase; EC 2.4.2.3) (Bzowska et al. 2000; Pugmire and Ealick 2002). TPase and UPase are functionally both pyrimidine nucleoside phosphorylases (PyNPase; EC 2.4.2.2.), although UPase is closer in sequence identity to PNPase than PyNPase (Lewkowicz and Iribarren 2006). PNPases are divided into two different classes depending on their tertiary and quaternary structures (Bzowska et al. 2000). Type I PNPases tend to be bacterial in origin and, based on sequence and structural information, appear to have a hexameric structure. Type II PNPases tend to be found in eukaryotes and, based on the sequence and structural information, are trimeric in structure (Bzowska et al. 2000; Pugmire and Ealick 2002). Bzowska et al. (2000) refer to type I PNPases as high molecular mass 
Fig. 1 Phosphorolysis of guanosine by purine nucleoside phosphorylase
Purine

nucleoside<smiles>Nc1nc2c(ncn2[C@@H]2O[C@H](CO)[C@@H](O)[C@H]2O)c(=O)[nH]1</smiles>

phosphorylase

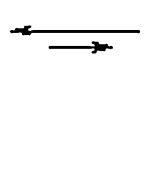<smiles>Nc1nc2[nH]cnc2c(=O)[nH]1</smiles>

Guanine

Ribose-1-phosphate
PNPases, and the type II PNPases as low molecular mass PNPases on the basis of their quaternary structures (Bzowska et al. 2000). In general, prokaryotic PNPases are more amenable to these transglycosylation reactions as they have broader specificity than their mammalian counterparts (Tonon et al. 2004). In addition, thermophiles have been shown to harbour enzymes that exhibit a much greater thermostability. For example, the thermophile Geobacillus stearothermophilus (previously Bacillus stearothermophilus) has two purine nucleoside phosphorylases which have been characterised (Hori et al. 1989a, b; Saunders et al. 1969) and applied in the synthesis of 5-methyluridine (Hori et al. 1989c, 1991). However, although these enzymes are thermostable, they have low levels of expression in the wild type. The genes have both been subsequently successfully expressed in $E$. coli at high levels (Hamamoto et al. 1996, 1997a, b).

The present work investigated the nucleoside phosphorylases present in the moderately thermophilic and alkaliphilic organism Bacillus halodurans Alk36 (Louw et al. 1993; Crampton et al. 2007). This organism was chosen due to its moderately thermophilic nature. It describes the cloning, heterologous expression in E. coli, purification, and evaluation of BHPNP1, a purine nucleoside phosphorylase from B. halodurans Alk36.

\section{Methods}

\section{Materials}

All restriction enzymes and the T4-DNA ligase were purchased from Fermentas (Lithuania). The Roche highfidelity PCR mix was used for all polymerase chain reactions. SDS-PAGE markers were purchased from Fermentas.

\section{Bioinformatics}

Owing to the high level of sequence identity between the genomes of B. halodurans Alk36 and B. halodurans C-125 the genome sequence of $B$. halodurans C-125 (Takami et al. 2000) (NC_002570), as published in the DNA Data Bank of Japan (http://gib.genes.nig.ac.jp), was searched for novel nucleoside phosphorylase gene sequences using the genomic BLAST (basic local alignment search tool; Altschul et al. 1990) located at the NCBI to confirm that no other PNPases or PyNPases were present apart from the annotated ones. Two PNPase and one PyNPase genes were identified. The two PNPases are BH1531 and BH1532, and the PyNPase was designated BH1533. Primers for the amplification of the PNPase gene BH1531 were designed based on the genome sequence. Isolation and characterisation of the gene corresponding to BH1531 from $B$. halodurans strain Alk36 was subsequently performed. This gene was termed BHPNP1.

\section{Genomic DNA isolation}

Bacillus halodurans Alk36 was grown overnight at $42^{\circ} \mathrm{C}$ in Luria Broth (LB) pH $8.5(10 \mathrm{~g} / \mathrm{L} \mathrm{NaCl} ; 10 \mathrm{~g} / \mathrm{L}$ tryptone, $5 \mathrm{~g} / \mathrm{L}$ yeast extract). Genomic DNA was isolated from $B$. halodurans according to the method of Lovett and Keggins (1979).

Cloning of the B. halodurans Alk36 PNPase gene

The PNPase gene designated BHPNP1 was amplified using the following primers: BH1531F 5'-GGACATATGCTT AACGTAACTCAATTG (NdeI site, underlined) and BH1531R 5'-GGTAAGCTTTTACATGTCTTTAACGA TTGC (HindIII site, underlined). PCR was performed using the high-fidelity polymerase from Roche (Germany). The PCR amplification protocol employed was as follows: a single 10 -min hold at $95^{\circ} \mathrm{C}$ was followed by 25 cycles of $1 \mathrm{~min}$ at $95^{\circ} \mathrm{C}, 1 \mathrm{~min}$ at $55^{\circ} \mathrm{C}$ and $1 \mathrm{~min}$ at $72^{\circ} \mathrm{C}$. A final 10 -min incubation at $72^{\circ} \mathrm{C}$ was followed by a $4^{\circ} \mathrm{C}$ hold. The size of the amplified product was confirmed on a $0.8 \%$ agarose gel and isolated using the Geneclean kit ${ }^{\mathrm{TM}}$ (Qbiogene, USA). The PCR product was ligated into pGEM-T Easy (Promega, USA). Restriction digests were performed with NdeI and HindIII to release the BHPNP1 insert.

The BHPNP1 gene was subsequently ligated using T4DNA ligase (Fermentas) into the pMS470 $\Delta 8$ expression vector (Balzer et al. 1992) restricted with NdeI and HindIII. This gave plasmid pMSPNP. This plasmid was transformed into E. coli JM109 (DE3) for expression analysis. 


\section{DNA sequencing}

The insert was sequenced at Inqaba Biotechnology (Pretoria, South Africa) using the PCR primers described above. The sequence was compared with the known nucleotide and amino acid sequence of the BH1531 gene from $B$. halodurans C-125 (protein sequence-BAB05250) and has been submitted to GenBank under the accession number GQ390428.

\section{Homology modelling}

Multiple sequence alignments were performed using ClustalW (Larkin et al. 2007). Homology modelling was performed using Accelrys Discovery Studio 2.0. A trimeric model was based on the bovine structure 1LVU (Bzowska et al. 2004). A second model was based on the monomeric structure 1VFN (Koellner et al. 1997). Bovine PNPase and BHPNP1 have $49 \%$ sequence identity and $61 \%$ sequence similarity (Table 1).

Growth and induction

Recombinant $E$. coli strains were grown in $50 \mathrm{ml} \mathrm{LB}$ medium with $100 \mu \mathrm{g} / \mathrm{ml}$ ampicillin, at $37^{\circ} \mathrm{C}$ with shaking at $200 \mathrm{rpm}$. Cultures were induced with $0.25 \mathrm{mM}$ IPTG when they had reached an $\mathrm{OD}_{600}$ between 0.05 and 0.1 . Cultures were subsequently grown at $30^{\circ} \mathrm{C}$ with shaking at $150 \mathrm{rpm}$ overnight for enzyme expression.

\section{Batch fermentations}

A 1.51 InFors HT batch fermentor (Labfors, Switzerland) containing 11 of GMO 20 medium was inoculated with a $50 \mathrm{ml}$ inoculum (overnight culture of E. coli JM109 [pMSPNP] in LB medium). The composition of the GMO 20 medium was as follows: $14.6 \mathrm{~g} / 1 \mathrm{~K}_{2} \mathrm{HPO}_{4}, 2 \mathrm{~g} / 1$ $\left(\mathrm{NH}_{4}\right)_{2} \mathrm{SO}_{4}, 3.6 \mathrm{~g} / 1 \mathrm{Na}_{2} \mathrm{HPO}_{4}, 2.5 \mathrm{~g} / \mathrm{l}$ citric acid, $1.2 \mathrm{~g} / \mathrm{l}$ $\mathrm{MgSO}_{4}, 5 \mathrm{~g} / \mathrm{NH}_{4} \mathrm{NO}_{3}$, and $20 \mathrm{~g} / \mathrm{l}$ yeast extract. Glucose $(17.5 \mathrm{~g} / \mathrm{l})$ and trace element solution $(5 \mathrm{ml} / \mathrm{l})$ was sterilized separately and added to the fermenters before inoculation.
Ampicillin $(100 \mu \mathrm{g} / \mathrm{ml})$ was aseptically added to the flasks containing the glucose and trace element solution. The trace element solution consisted of the following: $0.4 \mathrm{~g} / \mathrm{l}$ $\mathrm{CaCl}_{2} \cdot 2 \mathrm{H}_{2} \mathrm{O}, 16.7 \mathrm{~g} / 1 \mathrm{FeCl}_{3} \cdot 6 \mathrm{H}_{2} \mathrm{O}, 0.15 \mathrm{~g} / \mathrm{l} \mathrm{MnCl}_{2} .4 \mathrm{H}_{2} \mathrm{O}$, $0.18 \mathrm{~g} / 1 \quad \mathrm{ZnSO}_{4} .7 \mathrm{H}_{2} \mathrm{O}, \quad 0.125 \mathrm{~g} / 1 \quad \mathrm{CuCl}_{2} .2 \mathrm{H}_{2} \mathrm{O}$. $0.18 \mathrm{~g} / \mathrm{l}$ $\mathrm{CoCl}_{2} \cdot 6 \mathrm{H}_{2} \mathrm{O}$, and $20.1 \mathrm{~g} / 1 \mathrm{Na}_{2}$ EDTA. The $\mathrm{pH}$ of the fermentations was controlled at $\mathrm{pH} 7.2$ with $33 \% \mathrm{~m} / \mathrm{v} \mathrm{NH}_{4} \mathrm{OH}$

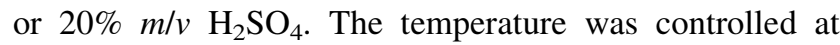
$37^{\circ} \mathrm{C}$ and the aeration set to $1 \mathrm{v} / \mathrm{v} / \mathrm{m}$. The starting agitation was set at $300 \mathrm{rpm}$ and ramped up manually to control the $\mathrm{pO}_{2}$ above $30 \%$ saturation. PNPase expression was induced at mid-log phase by adding IPTG to a final broth concentration of $0.5 \mathrm{mM}$. Fermentations were run for a further $4 \mathrm{~h}$ after induction.

Preparation of crude extract

After induction, the bacteria were harvested by centrifugation $(15,000 \mathrm{~g}, 20 \mathrm{~min})$. The pellet was re-suspended in minimal sterile deionised water, and subjected to a freezethaw cycle alternating between +20 and $-20^{\circ} \mathrm{C}$. Liberated protein was separated by centrifugation $(14,000 \mathrm{~g}, 10 \mathrm{~min})$ and stored. The pellet was re-suspended in 11 sterile deionised water and further disrupted using a cell disruptor (2 Plus, Constant Systems, UK) with 1 pass at $40 \mathrm{kpsi}$. Cellular debris was removed by centrifugation $(15,000 \mathrm{~g}$, $10 \mathrm{~min}$ ). The resultant protein solution (supernatants from freeze-thaw and cell disruption processes) were concentrated and washed once with sterile deionised water by ultrafiltration using an Amicon (Millipore, USA) stirred cell ultrafiltration unit $(30 \mathrm{kDa}$ cut-off polyethersulfone membrane). The final preparation was lyophilised in the presence of $1 \%$ maltose and 1\% PEG 8000 (Vertis Genesis 25 1). A portion of the lyophilised product, equivalent to $200 \mathrm{ml}$ original fermentation broth, was re-suspended in $20 \mathrm{mM}$ Tris- $\mathrm{HCl}$ buffer ( $\mathrm{pH}$ 7.5) for further purification.

\section{Column chromatography}

Anion exchange chromatography of each sample was performed on an AKTA Prime (Amersham Biosciences,
Table 1 Comparison of various PNPases to BHPNP1

\begin{tabular}{lllll}
\hline Protein & $\begin{array}{l}\text { Percentage of } \\
\text { protein identity }\end{array}$ & $\begin{array}{l}\text { Percentage of } \\
\text { protein similarity }\end{array}$ & $\begin{array}{l}\text { PNPase } \\
\text { type }\end{array}$ & $\begin{array}{l}\text { Accession } \\
\text { number }\end{array}$ \\
\hline E. coli PNP & 17.0 & 33.0 & I & P0ABP8 \\
E. coli XapA & 44.0 & 61.0 & II & NP_416902 \\
G. stearothermophilus PNP1 & 74.9 & 86.2 & II & P77834 \\
Bovine PNP & 47.1 & 61.1 & II & P55859 \\
Human PNP & 45.2 & 58.5 & II & P00491 \\
B. halodurans BH1532 & 57.1 & 75.6 & II & BAB05251 \\
B. subtilis PNP & 69.6 & 78.8 & II & P46354 \\
G. stearothermophilus PNP2 & 18.3 & 32.2 & I & P77835 \\
\hline
\end{tabular}


UK) using Toyopearl SuperQ650m anion exchange resin (Tosoh BioSep, USA). Protein was first eluted from the column using a salt gradient of between 50 and $500 \mathrm{mM}$ $\mathrm{NaCl}$ in $20 \mathrm{mM}$ Tris- $\mathrm{HCl} \mathrm{pH} 7.2$, over $400 \mathrm{ml}$ at a flow rate of $4 \mathrm{ml} / \mathrm{min}$. PNPase activity was assayed in all fractions (5 $\mathrm{ml}$ fractions collected) and those containing activity were separately pooled and concentrated by ultrafiltration (30 kDa membrane, Millipore USA). This sample was then re-applied to the anion exchange column and eluted over a salt gradient of $150-400 \mathrm{mM} \mathrm{NaCl}$. Active fractions were pooled and concentrated by ultrafiltration as above.

\section{Tertiary conformation}

Denatured $\left(5 \mathrm{~min}, 95^{\circ} \mathrm{C}\right)$ and non-denatured preparations of the enzyme were analysed on a 12\% SDS-PAGE gel. The gel was overlaid with a $0.5 \%$ agarose solution to determine the position of active subunits. The agarose solution contained $10 \mathrm{mM}$ inosine, $0.2 \mathrm{U} / \mathrm{ml}$ xanthine oxidase and $10 \mathrm{mM}$ INT (iodonitrotetrazolium violet) in $20 \mathrm{mM}$ sodium phosphate buffer, $\mathrm{pH} 7.5$. Active PNPase is indicated by a red/pink band on the gel due to the cascade action of the PNPase and xanthine oxidase leading to the reduction of INT to its tetrazolium salt. Positions of active and non-active units were then confirmed by staining the gel with Coomassie brilliant blue G-250.

PNPase assay

A volume $(10 \mu \mathrm{l})$ of suitably diluted sample was added to $190 \mu \mathrm{l}$ of $50 \mathrm{mM}$ sodium phosphate buffer containing $0.5 \mathrm{mM}$ inosine and $0.2 \mathrm{U} / \mathrm{ml}$ of xanthine oxidase in UV compatible microtitre plates (Thermomix) (Erion et al. 1997). The change in absorbance at $293 \mathrm{~nm}$ due to the liberation of uric acid was measured on a Powerwave HT microplate spectrophotometer (Biotek, USA). One unit of PNPase is defined as the amount of enzyme required to liberate $1 \mu \mathrm{mol}$ of uric acid from inosine, in the presence of an excess of xanthine oxidase, in $1 \mathrm{~min}$. The extinction coefficient $(\varepsilon)$ under these conditions was determined to be $7,454 \mathrm{~cm}^{2} / \mathrm{mol}$.

\section{Physical characteristics}

A $\mathrm{pH}$ profile was performed using reaction mixtures $(1 \mathrm{ml})$ containing $1 \mathrm{mM}$ guanosine in $50 \mathrm{mM}$ universal buffer $(50 \mathrm{mM}$ Tris, $50 \mathrm{mM}$ boric acid, $33 \mathrm{mM}$ citric acid $50 \mathrm{mM}$ $\mathrm{Na}_{2} \mathrm{PO}_{4}$ ), adjusted to $\mathrm{pH}$ values between 3 and 11 with either $\mathrm{HCl}$ or $\mathrm{NaOH}$. PNPase $(0.025 \mathrm{U})$ was added to initiate the reaction. After $10 \mathrm{~min}$ of incubation at $40^{\circ} \mathrm{C}$, the reaction was stopped by the addition of $0.5 \mathrm{ml}$ of a $5 \mathrm{M}$ $\mathrm{NaOH}$ solution. Guanosine conversion and guanine formation were analysed by HPLC on a Waters 2690 HPLC (interfaced with Waters Millennium Software) equipped with Waters 996 Photodiode Array Detector at $260 \mathrm{~nm}$ and a Phenomenex Synergi 4u Max-RP 80A, $150 \times 4.60 \mathrm{~mm}$ column at $22^{\circ} \mathrm{C}$. The mobile phase was $25 \mathrm{mM}$ ammonium acetate ( $\mathrm{pH} 4.0$ ), at a flow rate of $1.0 \mathrm{ml} / \mathrm{min}$.

The temperature optimum was determined with reaction mixtures $(1 \mathrm{ml})$ containing $1 \mathrm{mM}$ guanosine in $50 \mathrm{mM}$ sodium phosphate buffer, $\mathrm{pH}$ 8.0. PNPase $(0.025 \mathrm{U})$ was added to initiate the reaction. After $10 \mathrm{~min}$ of incubation at temperatures between $30^{\circ} \mathrm{C}$ and $90^{\circ} \mathrm{C}$, the reaction was stopped by the addition of $0.5 \mathrm{ml}$ of a $5 \mathrm{M} \mathrm{NaOH}$ solution. Guanosine conversion and guanine formation were analysed by HPLC as above. For temperature stability, enzyme solutions were incubated at temperatures between 40 and $70^{\circ} \mathrm{C}$. Samples were removed and analysed every $30 \mathrm{~min}$ for the first $2 \mathrm{~h}$, followed by less frequent sampling for a further $18 \mathrm{~h}$.

\section{Kinetic parameters}

The kinetic parameters for PNPase were determined for both inosine (standard assay) and guanosine (assay as described for temperature optimum study) as starting substrates. Initial substrate concentrations were varied between 0.05 and $1.0 \mathrm{mM}$. The reaction was stopped at 1, 2, 3, 4, 6 and $10 \mathrm{~min}$ to ensure measurements remained in the linear range. Michaelis-Menten plots and the linear transformations (Lineweaver-Burk, Hanes-Woolf and Eadie-Hofstee) were used to determine kinetic parameters.

\section{Results and discussion}

Sequence analysis and homology modelling

Bacillus halodurans is unusual amongst the Bacilli that have been completely sequenced so far in that it contains two type II PNPases as opposed to the types I and II PNPases present in other Bacillus species (unpublished data). The gene sequence of BHPNP1 was identical to that of BH1531 from B. halodurans $\mathrm{C}-125$ except for a silent substitution at nucleotide $519(\mathrm{C}-\mathrm{T})$, and hence the protein sequence was identical to that expressed by $B$. halodurans $\mathrm{C}-125$. BLAST analysis indicated that the closest related structure deposited in the protein data base (PDB) was that of the bovine PNP (Table 1; Fig. 2) which is $47 \%$ identical to BHPNP1. On the basis of sequence identity, BH1531 is a member of the type II PNPases.

BHPNP1 has low levels of identity to type I PNPases, such as E. coli PNP and G. stearothermophilus PNP2 (17 and $18.3 \%$ identity, respectively). It has higher levels of identity to type II PNPases. Selected type II PNPases were 
Fig. 2 Multiple sequence alignment comparing BHPNP1 to other type II PNPases BHPNP1 was aligned with $G$. stearothermophilus PNP1 (P77834) (Hamamoto et al. 1997a), bovine PNP (P55859) (Bzowska et al. 1995), human PNP (P00491) (Williams et al. 1984), B. subtilis PNP (P46354) (Schuch et al. 1999), the second B. halodurans PNP (BH1532, BAB05251) (Takami et al. 2000) and E. coli XapA (NP_416902) (Dandanell et al. 2005). The alignment was generated using ClustalW (Larkin et al. 2007;

http://www.ebi.ac.uk/clustalw). Residues shown to be important in the binding site of bovine and human PNPases are underlined (Mao et al. 1997, 1998; Montgomery et al. 1993; Narayana et al. 1997). Dots (. and :) indicate partial similarity and asterisks $(*)$ indicate a $100 \%$ match

Bovine
Human
B. halodurans
G. stearothermophilus
B.subtilis
BH1532
B. coli
Bovine
Human
B. halodurans
G. stearothermophilus
B.subtilis
BH1532
B. coli
Bovine
Human
B.halodurans
G. stearothermophilus
B. subtilis
BH1532
B. coli
Bovine
Human
B.halodurans
G. stearothermophilus
B. subtilis
BH1532
B. coli
Bovine
Human
B. halodurans
G.stearothermophilus
B.subtilis
BH1532
B. coli

aligned using ClustalW (Larkin et al. 2007). Amino acids known to be involved in the activity of the bovine and human enzymes (Lewkowicz and Iribarren 2006; Ealick et al. 1990) were generally conserved, with the exception of $\mathrm{Tyr}^{192}, \mathrm{Ser}^{234}, \mathrm{Met}^{236}$ and Ala ${ }^{237}$ in BHPNP1 and Cys ${ }^{115}$, $\mathrm{Tyr}^{193}, \mathrm{Met}^{194}, \mathrm{Ile}^{210}, \mathrm{Asp}^{236}, \mathrm{Met}^{237}$ and $\mathrm{Ala}^{238}$ in BH1532. These were all conservative substitutions with the exception of $\mathrm{Met}^{236}$ (BHPNP1), Cys ${ }^{115}$, Met ${ }^{194}$ and $\mathrm{Met}^{237}$ (BH1532). The position and orientation of these residues are shown in Fig. 3. Hence, it is likely that the active site, and overall tertiary structure, of BHPNP1 should resemble the bovine and human PNPases and is, therefore, likely to be a homotrimer. The structure of BHPNP1 was, hence, modelled based on the structure of the bovine PNPase (Fig. 3). This structure shows the modelled monomer, including a putative substrate, namely hypoxanthine. Residues that are known to be important in structure and function of the mammalian proteins and are conserved in BHPNP1 are indicated in yellow. Residues that are known to be important in structure and function of the mammalian proteins and are not conserved in BHPNP1 are indicated in red.

Tertiary conformation

BHPNP1 and G. stearothermophilus PNP1 are $74.9 \%$ identical. These proteins are likely to have similar
MANGYTYEDYQDTAKWLLSHTEQ-----RPQVAVICGSGLGGLVNKLTQAQT FDY SEIPN 55 MENG YT YED YKNTA ENL LSHTKH-----R PQVAI ICGSGGLGLTDKL TQA QI FDY GE IPN 55 ---MLNVTQL QEATT EI QQQIET-----RPT IGL IL GS GLGI LADEI EQPVKVPY SD IPH 52 ----MNRTAI EQAAO EL KER FPT -----S PQIGL IL GSGI GVLADEI EOA IK IPY SD IPN 51

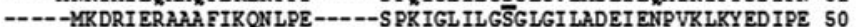
--MIN IREKVRQ SAEYLIGKIKN-----KPA IGL ILGSGLGEIANEI EEAVH IPYEQIPN 53 ---MSQVQESHNPL FC IDI IKT YRPDETPRVA FIL GS GLGA LADQI ENAVA ISY ERLPG 56

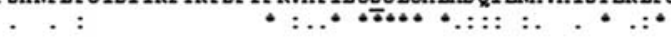

FPESTVPGHA GRLVEGILNGRACVMMGR FHMYEGYP FWKVT FPVRVERLIGVET LVVTN 115 FPRSTVPG HA GRLVE GEL NGRACVMO GR FHMYE GYPLWKVT FPVRV FHLLGVDTLVVTN 115 FPRS IV PGHA GRLVE GEL NGRACVMQGR FHMY GYPLW KVT FPVRV FHLLGVDT LVVTN 115

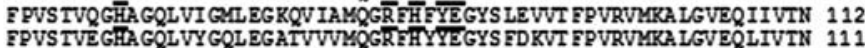

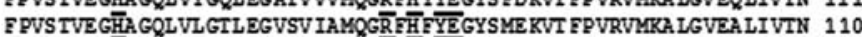
FPVS TVEGHA GQLVI GILHGRNVVAMQGR FH YYE GYTMQEVI FPVRVMIKE IGVEL IVVTN 113 FPVSTVHGHA GELVL GHLQGVPVVCMKGR G

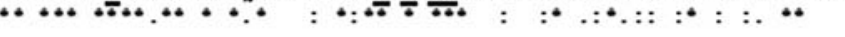

AAGGLNPNEEVGDIMLI RDH INL PGESGEN PLRGPNEEREGVREPAMSDA YDRDMRQRAH 175 ARGGLNPKEEVGDTMLI RDH INL PG FSGON PLRG PND ER FGDRFPAMSDA YDRTMRORAL 175 AAGGVES SFEAGDIMII RDH TNR---MAONPLIGPNDEA FGVR FPDMSNAYSERLRTLAR 169 AAGGVN SFE PGDIYII SDH INA---YGGNPLIGPNDSAIGVR FPDMSEAYSRRLROLAR 168 AAGGVNT EERAGDIMIIIDH INE---MGTNPLIGPNEAD RGARFPDMSSAYDRDLSSLAE 167

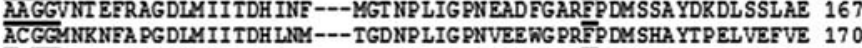

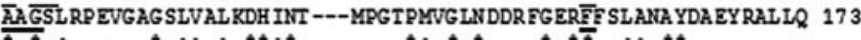

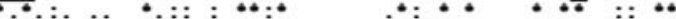

STWKQMGEQRELQEGTYVILGGPNEETVAECRLLRNLGADAVGUSTVPEV IVARHCGLRV 235 STWRQMGEQREIQE GTYYVMA GP SFETVA ECRVLQRIGADAVGISTVPEV IVARHCGLRV 235 ERGNT LN--LKLQEGVYVANT GPVYETPAEVRMI RRLGGDAVGYSTVPEVIVRRHAGLEV 227 DVANDIG--LRVR EGVYVANT GPAYETPAEI RMI RVMGGDAVGISTV PEVIVARHAGMEV 226 RIARDLN--I PIORGVYYT AVI GP SY ET ANRLD--I KVQRGVȲAGIT GPTYMTTGAEL IMLRNLGGDV IGYSTVPEVIVARHAGMKV 228 KVAREEG--FPLTEGVFVSY PGPNEETAAEI RMA IGGDVV GMSVVPEVISARHCDL KV 231

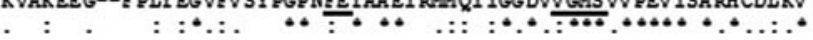

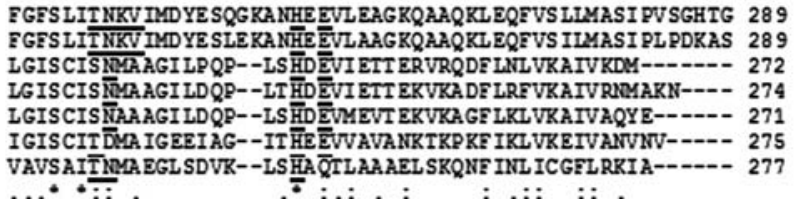

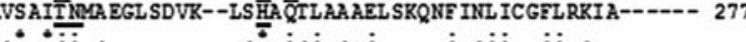

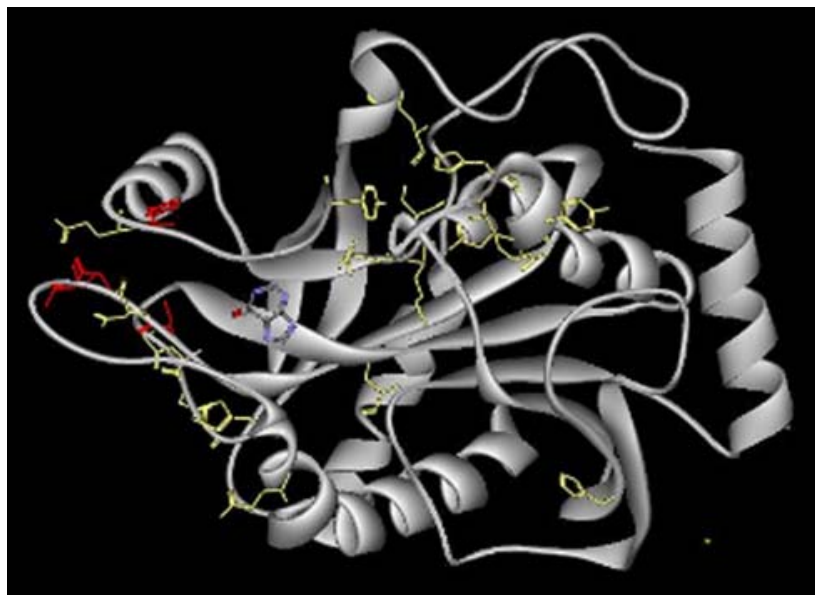

Fig. 3 Homology modelled three-dimensional structure of BHPNP1. Homology modelling of the BHPNP1 structure was performed using the bovine structure 1VFN (Koellner et al. 1997) as a template. The monomer was modelled along with the substrate, hypoxanthine

structural characteristics. As already mentioned by Hamamoto et al. (1997b), the high level of sequence identity between the G. stearothermophilus PNP1 and the eukaryotic PNPases strongly suggest structural similarity. This would also apply to the BHPNP1 protein. However, gel filtration analysis of the G. stearothermophilus PNP1 gave 


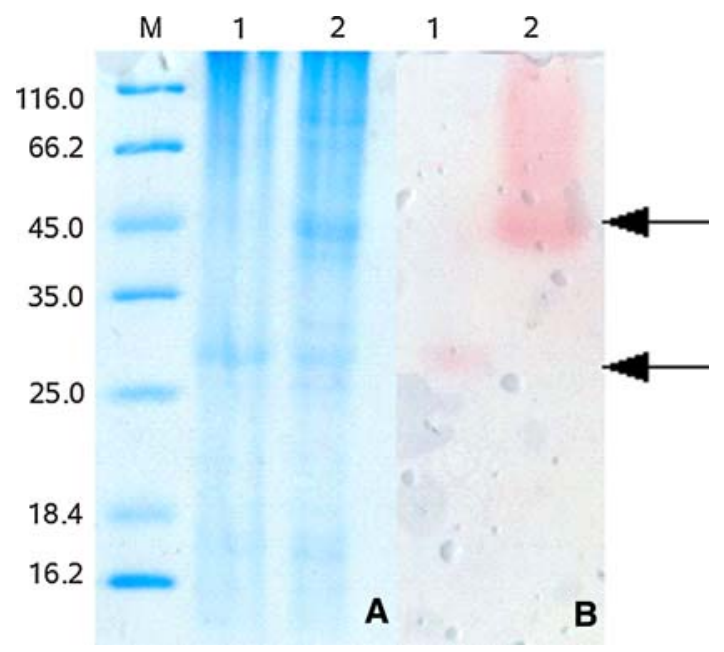

Fig. 4 12\% SDS PAGE gel (a) and corresponding activity gel overlay (b). $M$ marker, lane 1 heat-treated PNPase preparation $\left(95^{\circ} \mathrm{C}\right.$, 5 min); lane 2 non-heat-treated PNPase preparation. Arrows indicate the position of the monomer and the dimer

an apparent molecular weight of 68,000 , potentially indicating a dimeric protein (Hori et al. 1989b).

To confirm whether BHPNP1 is a trimer, which the sequence data suggests, or a dimer based on information about G. stearothermophilus PNP1 an overlay experiment was performed. The stained gel and overlay are shown in Fig. 4. The experiment indictated that the predominant tertiary confirmation was a dimer. The expected monomeric subunit was visible in both the heat-treated and nonheat-treated samples at approximately $27 \mathrm{kDa}$. Another dominant band at approximately $50 \mathrm{kDa}$ on the Coomassie stained gel (lane 2, Fig. 4a) was related to the active band on the overlay (lane 2, Fig. 4b). Hence, in contrast to the mammalian system, this enzyme appears to be dimeric.

Enzyme expression and purification

The productivity of $B$. halodurans Alk36 BHPNP1 heterologously expressed in E. coli JM109 (DE3) was $700 \mathrm{U} / \mathrm{l} / \mathrm{h}$ in shake flasks, but increased to $3,007 \mathrm{U} / \mathrm{l} / \mathrm{h}$ under the controlled fermentation conditions. PNPase was purified to $42 \%$ purity (by density analysis in SDS-PAGE, Fig. 5) and a specific activity of $30.2 \mathrm{U} / \mathrm{mg}$ total protein with a fold purification of 5.0 from the culture broth (Table 2).

\section{Physical characteristics}

PNPase showed a pH optimum of 7.0, retaining $60 \%$ activity between $\mathrm{pH} 5.7$ and 7.4 (Fig. 6). PNPase had optimum activity at $70^{\circ} \mathrm{C}$ and a broad activity range, retaining $60 \%$ activity between 30 and $74^{\circ} \mathrm{C}$ (Fig. 7). Although the optimum temperature of PNPase was shown to be $70^{\circ} \mathrm{C}$, only $7.2 \%$ activity remained after $30 \mathrm{~min}$

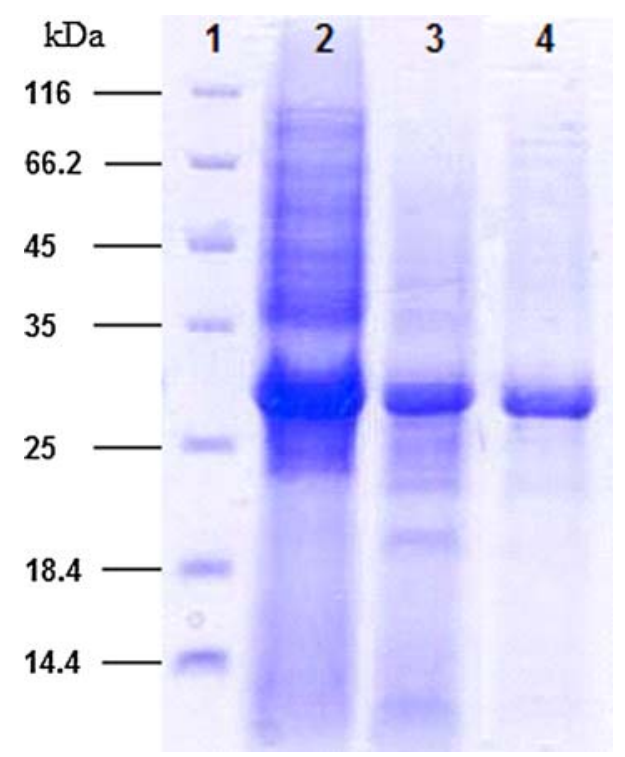

Fig. 5 Denaturing SDS-PAGE gel (12\%) showing successive purification steps. Various fractions from a purification of BHPNP were resolved using $12 \%$ SDS-PAGE. Lane 1 protein marker sizes in kilodaltons, lane 2 crude extract, lane 3 concentrated sample after anion exchange column 1, lane 4 final sample after anion exchange column 2

incubation at this temperature $\left(t_{1 / 2}-15.2 \mathrm{~min}\right)$. PNPase did, however, show good stability at $60^{\circ} \mathrm{C}\left(t_{1 / 2}-20.8 \mathrm{~h}\right)$ and excellent stability at $40^{\circ} \mathrm{C}$, with no change in activity over the time period $(19 \mathrm{~h})$.

\section{Kinetic characterisation}

Linear transformation of velocity data obtained for varying initial substrate concentrations showed good linear regression fit where inosine was used $\left(R^{2}>99 \%\right.$ for all plots) and adequate fit for guanosine experiments $\left(R^{2}>94 \%\right)$. From the plots (Lineweaver-Burk, EadieHofstee and Hanes-Woolf), $K_{\mathrm{m}}$ and $V_{\max }$ were determined with $<7 \%$ deviation in the values calculated from the three plots. Subsequently, the turnover number $\left(k_{\text {cat }}\right)$ and the specificity constant were calculated. These values are summarised in Table 3.

The PNP1 from the thermophile G. stearothermophilus has been previously expressed and characterised (Hori et al. 1989a; Hamamoto et al. 1997a). The G. stearothermophilus enzyme has a $\mathrm{pI}$ of 4.7 , with an optimal $\mathrm{pH}$ range between 7.5 and 11, in contrast to the optimal $\mathrm{pH}$ range of BHPNP1 of between 5.7 and 8.4 and a predicted $p \mathrm{I}$ of 5.1. The G. stearothermophilus PNPase is more thermostable then BHPNP1 as it is stable at $70^{\circ} \mathrm{C}$ for greater then $30 \mathrm{~h}$. In contrast, the half life of PNPase BHPNP 1 at $60^{\circ} \mathrm{C}$ is 20 h. G. stearothermophilus PNPase $K_{\mathrm{m}}$ for inosine was similar at $0.22 \mathrm{mM}$, but had a greater affinity for guanosine at $K_{\mathrm{m}}$ of $0.14 \mathrm{mM}$. 
Table 2 Fold purification table for the purification of recombinant BHPNP1

\begin{tabular}{lcccc}
\hline & Total units & Specific activity & Percentage of recovery (\%) & Fold purification \\
\hline Initial culture (intracellular) & 4,840 & 6.93 & 100.00 & 1.00 \\
Lyophilised crude extract & 732 & 20.65 & 15.12 & 2.97 \\
Ion exchange 1 (0-500 mM NaCl gradient) & 541 & 22.24 & 11.17 & 3.73 \\
Ion exchange 2 (150-400 mM NaCl gradient) & 110 & 30.23 & 2.27 & 4.99 \\
\hline
\end{tabular}

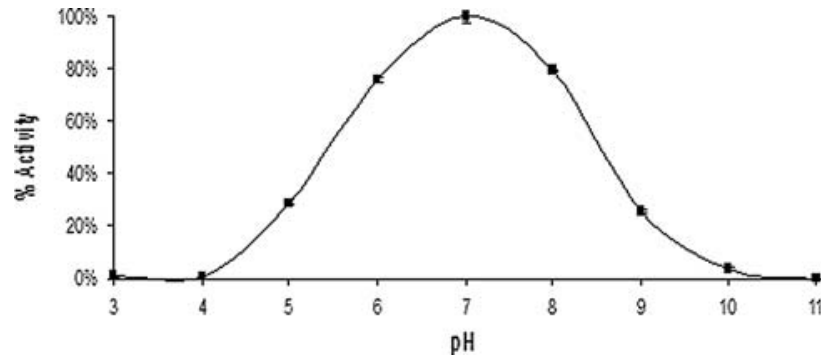

Fig. $6 \mathrm{pH}$ optimum profiles of BHPNP1. A pH profile was performed using reaction mixtures $(1 \mathrm{ml})$ containing $1 \mathrm{mM}$ guanosine in $50 \mathrm{mM}$ universal buffer $(50 \mathrm{mM}$ Tris, $50 \mathrm{mM}$ boric acid, $33 \mathrm{mM}$ citric acid; $50 \mathrm{mM} \mathrm{Na} 2 \mathrm{PO}_{4}$ ), adjusted to $\mathrm{pH}$ values between 3 and 11 with either $\mathrm{HCl}$ or $\mathrm{NaOH}$. PNPase $(0.025 \mathrm{U})$ was added to initiate the reaction. After $10 \mathrm{~min}$ of incubation at $40^{\circ} \mathrm{C}$, the reaction was stopped by the addition of $0.5 \mathrm{ml}$ of a $5 \mathrm{M} \mathrm{NaOH}$ solution. Guanosine conversion and guanine formation were analysed by HPLC at $260 \mathrm{~nm}$. The mobile phase was $25 \mathrm{mM}$ ammonium acetate $(\mathrm{pH} 4.0)$, at a flow rate of $1.0 \mathrm{ml} / \mathrm{min}$

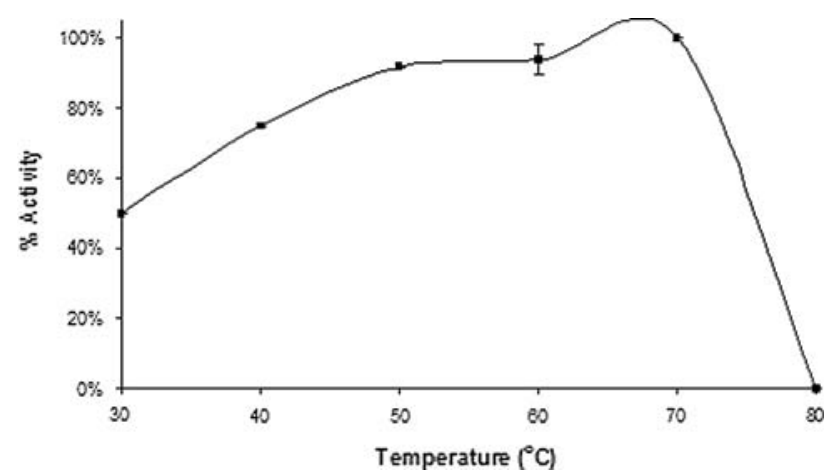

Fig. 7 Temperature optimum profile of BHPNP1. The temperature optimum of BHPNP1 was determined with reaction mixtures containing $1 \mathrm{mM}$ guanosine in $50 \mathrm{mM}$ sodium phosphate buffer, $\mathrm{pH}$ 8.0. PNPase $(0.025 \mathrm{U})$ was added to initiate the reaction. After $10 \mathrm{~min}$ of incubation at temperatures between 30 and $90^{\circ} \mathrm{C}$, the reaction was stopped by the addition of $0.5 \mathrm{ml}$ of a $5 \mathrm{M} \mathrm{NaOH}$ solution. Guanosine conversion and guanine formation were analysed by HPLC

\section{Conclusions}

The thermostable type II nucleoside phosphorylase from the bacterium B. halodurans Alk36 was expressed heterologously in $E$. coli, purified, and functionally characterised.
Table 3 Physical and kinetic characteristics of BHPNP1

\begin{tabular}{lll}
\hline Parameter (units) & Inosine & Guanosine \\
\hline Specific activity $\left(\mathrm{U} \mathrm{mg}^{-1}\right)$ & 30.23 & $\mathrm{ND}$ \\
$K_{\mathrm{m}}(\mu \mathrm{M})$ & 236 & 206 \\
$V_{\max }\left(\mathrm{mol} \mathrm{s}^{-1}\right)$ & $4.76 \times 10^{-6}$ & $2.03 \times 10^{-9}$ \\
$k_{\text {cat }}\left(\mathrm{s}^{-1}\right)$ & $2.8 \times 10^{4}$ & $1.2 \times 10^{1}$ \\
Specificity constant $\left(\mathrm{M}^{-1} \mathrm{~s}^{-1}\right)$ & $1.2 \times 10^{8}$ & $5.87 \times 10^{4}$ \\
$\mathrm{pH}$ Opt & 7 & \\
pH range $(60 \%)$ & $5.7-8.4$ & \\
Temp Opt $\left({ }^{\circ} \mathrm{C}\right)$ & 70 & \\
Temp range $(60 \%)\left({ }^{\circ} \mathrm{C}\right)$ & $32-74$ & \\
Temp stability $\left(t_{1 / 2}\right.$ at $\left.60^{\circ} \mathrm{C}\right)(\mathrm{h})$ & 20.8 & \\
Temp stability $\left(t_{1 / 2}\right.$ at $\left.40^{\circ} \mathrm{C}\right)(\mathrm{h})$ & $>200$ & \\
\hline
\end{tabular}

The enzyme was capable of phosphorolysis of guanosine to yield guanine and ribose-1-phosphate, the latter of which may be used in the enzymatic glycosylation of nucleosides.

Acknowledgments We would like to thank Dr D. R. Walwyn (CEO of Arvir Technologies) for support for this project, as well as Zimkhitha Sotenjwa, Dr Anu Idicula and Dr Neeresh Rohitlall who helped lay the foundations for this research. We gratefully acknowledge the financial support, and resources from CSIR Biosciences, LIFElab and Arvir Technologies in funding this project, without which this work would not have been possible.

Open Access This article is distributed under the terms of the Creative Commons Attribution Noncommercial License which permits any noncommercial use, distribution, and reproduction in any medium, provided the original author(s) and source are credited.

\section{References}

Altschul SF, Gish W, Miller W, Myers EW, Lipman DJ (1990) Basic local alignment search tool. J Mol Biol 215:403-410

Balzer D, Ziegelin G, Pansegrau W, Kruft V, Lanka E (1992) KorB protein of promiscuous plasmid RP4 recognizes inverted sequence repetitions in regions essential for conjugative plasmid transfer. Nucl Acids Res 20:1851-1858

Bzowska A, Luić M, Schröder W, Shugar D, Saenger W, Koellner G (1995) Calf spleen purine nucleoside phosphorylase: purification, sequence and crystal structure of its complex with an N(7)acycloguanosine inhibitor. FEBS Lett 367:214-218 
Bzowska A, Kulikowska E, Shugar D (2000) Purine nucleoside phosphorylases: properties, functions, and clinical aspects. Pharmacol Therapeut 88:349-425

Bzowska A, Koellner G, Wielgus-Kutrowska B, Stroh A, Raszewski G, Holý A, Steiner T, Frank J (2004) Crystal structure of calf spleen purine nucleoside phosphorylase with two full trimers in the asymmetric unit: important implications for the mechanism of catalysis. J Mol Biol 342:1015-1032

Crampton M, Berger E, Reid S, Louw M (2007) The development of a flagellin surface display expression system in a moderate thermophile, Bacillus halodurans Alk36. Appl Microbiol Biotechnol 75:599-607

Dandanell G, Szczepanowski RH, Kierdaszuk B, Shugar D, Bochtler M (2005) Escherichia coli purine nucleoside phosphorylase II, the product of the xapA gene. J Mol Biol 348:113-125

Ealick SE, Rule SA, Carter DC, Greenhough TJ, Babu YS, Cook WJ, Habash J, Helliwell JR, Stoeckler JD, Parks RE Jr (1990) Threedimensional structure of human erythrocytic purine nucleoside phosphorylase at 3.2 A resolution. J Biol Chem 265:1812-1820

Erion MD, Takabayashi K, Smith HB, Kessi J, Wagner S, Hönger S, Shames SL, Ealick SE (1997) Purine nucleoside phosphorylase. 1. Structure-function studies. Biochemistry 36:11725-11734

Ge C, Ouyang L, Ding Q, Ou L (2009) Co-expression of recombinant nucleoside phosphorylase from Escherichia coli and its application. Appl Biochem Biotechnol 159:168-177

Hamamoto T, Noguchi T, Midorikawa Y (1996) Purification and characterization of purine nucleoside phosphorylase and pyrimidine nucleoside phosphorylase from Bacillus stearothermophilus TH 6-2. Biosci Biotechnol Biochem 60:1179-1180

Hamamoto T, Okuyama K, Noguchi T, Midorikawa Y (1997a) Cloning and expression of purine nucleoside phosphorylase I gene from Bacillus stearothermophilus TH 6-2. Biosci Biotechnol Biochem 61:272-275

Hamamoto T, Noguchi T, Midorikawa Y (1997b) Cloning of purine nucleoside phosphorylase II gene from Bacillus stearothermophilus TH 6-2 and characterization of its gene product. Biosci Biotechnol Biochem 61:276-280

Hori N, Watanabe M, Yamazaki Y, Mikami Y (1989a) Purification and characterisation of thermostable purine nucleoside phosphorylase of Bacillus stearothermophilus JTS 859. Agric Biol Chem 53:2205-2210

Hori N, Watanabe M, Yamazaki Y, Mikami Y (1989b) Purification and characterization of second thermostable purine nucleoside phosphorylase in Bacillus stearothermophilus JTS 859. Agric Biol Chem 53:3219-3224

Hori N, Watanabe M, Yamazaki Y, Mikami Y (1989c) Synthesis of 5methyluridine by a thermophile, Bacillus stearothermophilus JTS 859. Agric Biol Chem 53:197-202

Hori N, Watanabe M, Sunagawa K, Uehara K, Mikami Y (1991) Production of 5-methyluridine by immobilized thermostable purine nucleoside phosphorylase and pyrimidine nucleoside phosphorylase from Bacillus stearothermophilus JTS 859. J Biotechnol 17:121-131

Koellner G, Luić M, Shugar D, Saenger W, Bzowska A (1997) Crystal structure of calf spleen purine nucleoside phosphorylase in a complex with hypoxanthine at $2.15 \AA$ resolution. J Mol Biol 265:202-216

Larkin MA, Blackshields G, Brown NP, Chenna R, McGettigan PA, McWilliam H, Valentin F, Wallace IM, Wilm A, Lopez R,
Thompson JD, Gibson TJ, Higgins DG (2007) Clustal W and Clustal X version 2.0. Bioinformatics 23:2947-2948

Lewkowicz E, Iribarren A (2006) Nucleoside phosphorylases. Curr Org Chem 10:1197-1215

Louw ME, Reid SJ, Watson TG (1993) Characterization, cloning and sequencing of a thermostable endo-(1, 3-1, 4) beta-glucanaseencoding gene from an alkalophilic Bacillus brevis. Appl Microbiol Biotechnol 38:507-513

Lovett PS, Keggins KM (1979) Bacillus subtilis as a host for molecular cloning. Method Enzymol 68:342-357

Mao C, Cook WJ, Zhou M, Koszalka GW, Krenitsky TA, Ealick SE (1997) The crystal structure of Escherichia coli purine nucleoside phosphorylase: a comparison with the human enzyme reveals a conserved topology. Structure 5:1373-1383

Mao C, Cook WJ, Zhou M, Federov AA, Almo SC, Ealick SE (1998) Calf spleen purine nucleoside phosphorylase complexed with substrates and substrate analogues. Biochemistry 37:7135-7146

Medici R, Porro MT, Lewkowicz E, Montserrat J, Iribarren AM (2008) Coupled biocatalysts applied to the synthesis of nucleosides. Nucleic Acids Symp Ser 2008:541-542

Montgomery JA, Niwas S, Rose JD, Secrist JA, Babu YS, Bugg CE, Erion MD, Guida WC, Ealick SE (1993) Structure-based design of inhibitors of purine nucleoside phosphorylase. 1. 9-(arylmethyl) derivatives of 9-deazaguanine. J Med Chem 36:55-69

Narayana SV, Bugg CE, Ealick SE (1997) Refined structure of purine nucleoside phosphorylase at $2.75 \AA$ resolution. Acta Crystallogr D 53:131-142

Prasad A, Trikha S, Parmar V (1999) Nucleoside synthesis mediated by glycosyl transferring enzymes. Bioorg Chem 27:135-154

Pugmire MJ, Ealick SE (2002) Structural analyses reveal two distinct families of nucleoside phosphorylases. Biochem J 361:1-25

Rocchietti S, Ubiali D, Terreni M, Albertini AM, Fernández-Lafuente R, Guisán JM, Pregnolato M (2004) Immobilization and stabilization of recombinant multimeric uridine and purine nucleoside phosphorylases from Bacillus subtilis. Biomacromolecules 5:2195-2200

Saunders PP, Wilson BA, Saunders GF (1969) Purification and comparative properties of a pyrimidine nucleoside phosphorylase from Bacillus stearothermophilus. J Biol Chem 244:36913697

Schuch R, Garibian A, Saxild HH, Piggot PJ, Nygaard P (1999) Nucleosides as a carbon source in Bacillus subtilis: characterization of the drm-pupG operon. Microbiology 145:2957-2966

Takami H, Nakasone K, Takaki Y, Maeno G, Sasaki R, Masui N, Fuji F, Hirama C, Nakamura Y, Ogasawara N, Kuhara S, Horikoshi K (2000) Complete genome sequence of the alkaliphilic bacterium Bacillus halodurans and genomic sequence comparison with Bacillus subtilis. Nucleic Acids Res 28:4317-4331

Tonon G, Capra E, Orsini G, Zuffi G (2004) Novel immobilized biocatalysts usable for the production of natural nucleosides and modified analogues by enzymatic transglycosylation reactions. US Patent Number 20040142438

Utagawa T (1999) Enzymatic preparation of nucleoside antibiotics. J Mol Catal B Enzym 6:215-222

Williams SR, Goddard JM, Martin DW (1984) Human purine nucleoside phosphorylase cDNA sequence and genomic clone characterization. Nucleic Acids Res 12:5779-5787 